\title{
The Analysis of Oral Variety in Medan City
}

\author{
Adelina Ginting ${ }^{1}$ \\ ${ }^{1}$ Universitas Katolik Santo Thomas, Indonesia \\ Email: adelinaginting57@gmail.com
}

\begin{abstract}
The research is aimed to describe the oral variety that is used by the people in Medan City. The location of this research was carried out in Medan City, Lingkungan II Titi Rantai Padang Bulan Medan. This study uses a qualitative method. Sources of data obtained from the visitors in 5 coffee shop in Lingkungan II Titi Rantai Padang Bulan. Results of the study showed the oral variety which is used in the form of abbreviations said among other things: Mandi, Nurdin , Martabe, the oral variety in the form of words that are influenced from the language of the area among others, bagudung, lalap, lateung, in addition to the many found the use of language phenomenon those are: Apheresis namely the removal of sound (phoneme) at the beginning of the word: saja - aja, Syncope namely removal of noise in the middle of the word: Tahu-tau, Haplology namely the removal of some phoneme in the middle of the word: Sedikit-dikit, Paragog namely the addition of sound at the end of words: Muka-mukak, Construction purposes, namely a combination of two pieces of words into a word: Bagai-Mana-Bagaimana, Monophothongization namely change two sounds vowels into one vowel: Sampesampai, Hypercorrection namely changing one phoneme into phoneme others: Pelit-celit .
\end{abstract}

Keywords: Language Phenomenon, Oral Variety, Medan City

\section{Introduction}

As we all know the Indonesian language spread widely to the entire archipelago. The extent of the territory the use of Indonesian language that gives rise to differences in the use of language. The Indonesian language is used in an area different from the Indonesian language which is used in one area to another. For example, the Indonesian language which is used by people who live in Jayapura is different from the Indonesian language which is used in Medan, Indonesian language that used in Denpasar is different from the Indonesian language which is used in Jakarta. The use of languages is different because of the differences in areas such as the so-called wide area or a term that has been long known as a so-called accent. The most prominent accent / visible and easy to observe is pronunciation. The Indonesian accent of Javanese people can be seen in the pronunciation of $/ \mathrm{b} /$ at the initial position of city names, such as mBogor, mBandung, mBali, and mBanyuwangi or the realization of the pronunciation of words, such as pendidi'an, tabra'an , kenai'an, and gera'an. The accent of Indonesian language in Bali and Aceh people will appear in the actual pronunciation of / $\mathrm{t} /$ as retroflek, as appears in the word thethapi, canthik, Ithu, and Kitha. The accent in Tapanuli appear in the realization of pronunciation / e / and pressure said that very clear, as appears in the séméntara itu, séwénang-wénang, lébaran, and gélang. The characteristics of pressure, down rising tone, and length in short sound language from the accents are different. Differences vocabulary words or system layout language are also marked differences in dialect, but not as clear pronunciation. English mother or the language

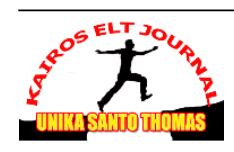




\section{KAIROS ELT JOURNAL, Vol. 5 No. 2 Agustus 2021 Copyright $\bigcirc 2021$, ISSN: 2580-4278}

that dominated the first close hubungunannya with accent or a wide area / dialect. Differences in dialect Indonesian language anatara area are one and areas that others usually can be accepted or not at issue during the language that is used it can be understood and does not interfere with the smooth communication. Not infrequently we find that the difference in a wide area / accent in between the tribes of the nation in the archipelago is used as ingredient of humor. Who was educated also appear in the field of grammar language, for example, mbawa membawa, nyari mencari or in the composition of the sentence ini hari kita orang akan ke Bandung? Likewise, the use of the sentence "Saya akan ceritakan tentang Timun Emas" shows that her followers are less able to maintain their language. Variety of language which is spoken by a group of speakers educated it has the characteristics of the continuance. Variety of languages that are used in the world of education, institutions of government, media, mass, science and technology. Variety that has prestige are high.

Variety of language is influenced also by the attitude of the speaker towards comrades talk (if oral) or the attitude of the writer to the reader (if written). The attitude that the other official, familiar, cool and relaxed. Also, on the contrary, the position of fellow talk or reader to the speaker or writer affect the attitude of the. For example, we can observe the language of a subordinate or officer when reporting to his boss or his boss, language command superiors to subordinates, the language of a mother who persuaded her son, language of the parents who were scolding her child, or the language of children younger who were talking in a relaxed. Of course, we can also observe the language of the application letter / job application which is different from the language of the love letters of two teenagers. The differences were visible in the choice of words and the application of the rules of grammar language. Often also called a mini body style. In basically every speakers of the language have the ability to wear a variety of diverse languages it. However, the skills using a variety of diverse language that is not an inheritance but can be obtained through the process of learning, either through training or experience. The limitation in mastering the variety of language style give rise to the impression that the speaker was less extensive in socializing. For example, a child that only have one kind of style, which are used in environments family will use that language style in all situations. Conversely, people who only use one kind of style, For example, when ordering something, for a variety of situations will give rise to the impression that the people that do not want to be familiar with the comrades talk (Sugono, 1994).

From the description in the above, the research is conducted is limited in the oral variety in 5 coffee shop on the community in Lingkungan II Titi Rantai Padang Bulan, Medan. Sample a variety of verbal which is found in the stalls of coffee:

Customer 1: Bang, order 1 mandi, robak 1

Waiter : Okay bro

Customer 2: Bang, pisbak 1, martabe 1

Waiter : Okay bro

From the example at the top, people in Medan City often using short terms so that some people who come from outside the city of Medan do not understand the oral variety which is used by the community of Medan City. For it is necessary to do research so that the terms are used in a variety of oral that can be understood by the public general.

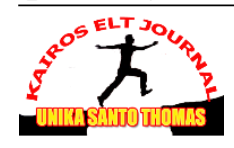


KAIROS ELT JOURNAL, Vol. 5 No. 2 Agustus 2021

Copyright $\bigcirc 2021$, ISSN: 2580-4278

\section{Literature Review}

\section{Language Symptoms}

Changes in the form of words, both the language Indonesia and the language of the area that became the language of jargon can be called with symptoms of language. This is in line with the opinion of Muslich (2009: 101) which reveals that changes in the form of any word in a language are commonly referred to as language symptoms. In addition to Muslich , Badudu (1985: 47) explains that language symptoms are events that involve the formation of words or sentences with all kinds of formation processes . Muslich (2009: 101-109) describes various symptoms of language, namely analogy, adaptation, contamination, hypercorrection, variant, assimilation , dissimilation, addition, reduction, metathesis, diphthongization, monophthongization, anaptiksis, haplology, and contraction. JS Badudu (1985) also describes several types of language symptoms, namely analogy, contamination, hypercorrection, addition of phonemes, omission of phonemes, contractions, metathesis, and adaptation. Based on the two opinions of experts on the above it can be concluded that the symptoms of a language is a change in shape in a word. Changes in the shape it allows the emergence of a vocabulary newly even have a meaning that is different . These language symptoms can be divided into 15 types, namely analogy, adaptation, contamination , hypercorrection, variant, assimilation, dissimilation , addition ( addition of phonemes ), reduction ( deletion of phonemes ), metathesis, diphthongization , monophthongization, anaptiksis, haplology, and contraction .

1. Analogy

Muslich (2009: 101) reveals the analogy is a formation of a language to imitate the example that already exist. In a language that is growing and developing, the formation of new words ( analogy ) is very important because the formation of new words can enrich the vocabulary of the language. Understanding analogy according to Masnur Muslich are in line with the understanding that proposed by Badudu (1985: 47) which defines analogy as a derivative language that imitate the example that already exist . Based on the two opinions of experts that it can be concluded that the symptoms of a language analogy is a form of language that mimic the language that already exist. For example : gods, sons and daughters, students, students, young people, wealthy, handsome, sportsmen, and nobles .

2. Adaptation

According Badudu (1985: 65) symptom adaptation are words adoptee are taken from a language alien who changed the sound in accordance with the acceptance of hearing or speech tongue of Indonesia. Understanding adaptation that according to the understanding of the symptoms of adaptation which is expressed by Masnur Muslich in his book that called Tata Forms Indonesian. Muslich (2009: 103) reveals that the phenomenon of adaptation is a change in the sound and structure of the language alien into the sound and structure are in accordance with the acceptance of hearing or speech tongue nation wearer language are entered. Based on the two opinions of experts that it can be concluded that the phenomenon of adaptation is the adjustment of sound and structure of a language foreign to the language of Indonesia. Adaptation or adjustment can be differentiated into two , namely adaptation phonological and adaptation morphologically . 
KAIROS ELT JOURNAL, Vol. 5 No. 2 Agustus 2021

Copyright@2021, ISSN: 2580-4278

a. Adaptation phonological are adjustments change the sound of the language alien into sounds that correspond to the speech of the tongue nation wearer language are entered. Adaptation is emphasizing the pronunciation of sounds , for example, as follows :

voolopoer (Netherlands) -> pioneer

dhahir (Arabic) -> born

b. Morphological adaptation is the adjustment of the structure of the word form. Changes in the structure of the word is of course only an effect on the change in sound. For example, the word following this:

parameswari (Sanskrit) -> empress

tempest (Sanskrit) -> matter

\section{Contamination}

Muslich (2009: 103) reveals that in Indonesian, the word contamination is the same as confusion. The word ambiguous means 'mixed up', 'overlapping', chaotic'. In the field of language, the word ambiguity is used as a term related to the inappropriate mixing of two language elements (affixes, words, phrases, or sentences). This is in line with the notion of contamination expressed by Badudu (1985: 51) revealing that contamination is a symptom of language which in Indonesian is termed confusion. Based on the two expert opinions, it can be concluded that the symptom of contamination is an unnatural or ambiguous word formation due to the mixing of two elements of unnatural language. The impropriety that shows the ambiguous form (especially the word formation) can be seen in the following example: nationalized, published, expanded, exalted 4. Hypercorrect According to Muslich (2009: 104) hypercorrection symptoms are a process of correcting a shape that is already correct and then becomes wrong. That is, something that has been corrected again will eventually turn out to be wrong or at least be considered a non-standard form. This is in accordance with the notion of hypercorrection symptoms according to Badudu (1985: 58) which reveals that hypercorrection symptoms are a process of formation that is completely reversed. That is, what has been corrected again ends up being wrong. Kridalaksana (2008: 83) reveals that the hypercorrection symptom is related to the form or use of the word incorrectly because it avoids the use of substandard. Based on the definition of hypercorrection from these experts, it can be concluded that the symptom of hypercorrection is the correction of a correct or standard form of a word but it becomes wrong and is no longer true. Symptoms of hypercorrection can be seen in the following examples: a. The phoneme /s/ becomes /sy/: healthy to healthy; be converted; nerves become nerves. b. Phoneme $/ \mathrm{h} /$ becomes $/ \mathrm{kh} /$ : expert becomes expert; uterus becomes rakhim; animals become animals.

\section{Methods}

Scientific writing must use a good method, because the method is a way of working in order to understand the object that is the target of the science concerned. With the use of the right method can solve the problem well too. The method used as the basis for solving problems in oral variety in the people of the city of Medan. The method used can be divided into two, namely the subjective or intuitive method, where the researcher is actively involved as an informant. Subjective or intuitive methods are used in this study with a value-deplomatory approach. While

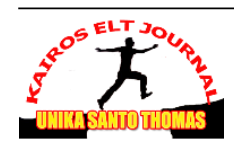




\section{KAIROS ELT JOURNAL, Vol. 5 No. 2 Agustus 2021}

Copyright $\bigcirc 2021$, ISSN: 2580-4278

the objective method includes descriptive or depiction (Baried 1983:6) From the methods mentioned above, the most appropriate method to be applied in this study is the combined method of subjective and objective methods. In compiling a written work, especially a scientific one, of course, a good method must be used; with the right method of solving a good problem. The object of this research is the oral variety in the people of the city of Medan. The method used in analyzing oral variety in the people of Medan city is a qualitative descriptive method.

\section{Results and Discussion}

Indonesian Dictionary states that the definition of a word or a combination of words that carefully expresses the meaning of a concept, process, condition, or characteristic that is unique in a particular field (KBBI, 1988)

\begin{tabular}{|c|c|c|}
\hline Conversation & Short Terms & Explanation \\
\hline 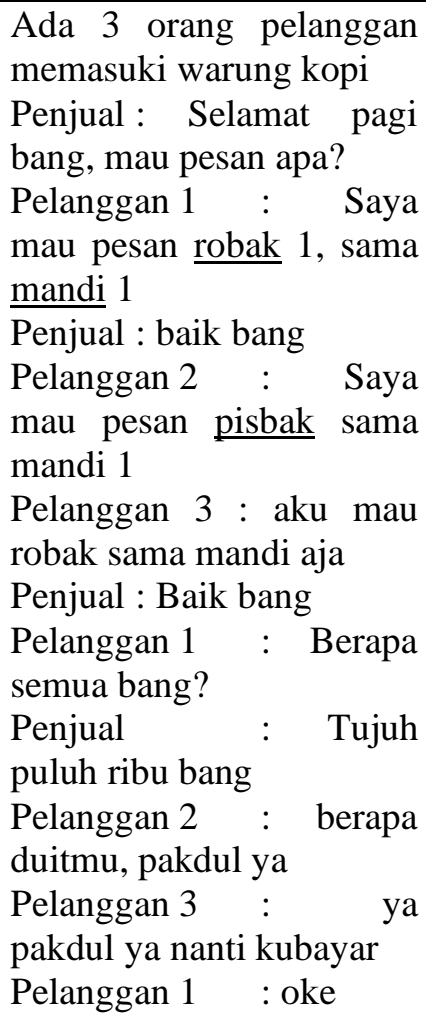 & $\begin{array}{ll}- & \text { Mandi } \\
- & \text { Robak } \\
- & \text { Pisbak } \\
- & \text { Pakdul }\end{array}$ & $\begin{array}{l}\text { Mandi comes from the words: } \\
\text { Manis - Man } \\
\text { Dingin - Di } \\
\text { Robak berasal dari kata: } \\
\text { Roti - Ro } \\
\text { Bakar - Bak } \\
\text { Pisbak comes from the words: } \\
\text { Pisang - Pis } \\
\text { Bakar - Bak } \\
\text { Pakdul comes from the words: } \\
\text { Pakai - Pak } \\
\text { Dulu - Dul } \\
\text { Abbreviations of "Mandi" were } \\
\text { referred to as the cold sweat tea. But } \\
\text { often once said the it was not used in } \\
\text { communication }\end{array}$ \\
\hline $\begin{array}{l}\text { Komunikasi di Warkop E } \\
\text { Penjual : Mau pesan apa } \\
\text { bang? } \\
\text { Pelanggan: Kari ayam ya } \\
\text { kak } \\
\text { Penjual : } \quad \text { Minumnya } \\
\text { bang? } \\
\text { Pelanggan: Kopsu aja }\end{array}$ & $\mathbf{S u}$ & $\begin{array}{l}\text { - Berasal dari kata } \\
\text { Kopi - Kop } \\
\text { Susu - Su } \\
\text { The phrases of "Kopsu aja" it should be } \\
\text { "kopi susu saja" (coffe milk only), there } \\
\text { is an omission at the beginning of the } \\
\text { word, namely "saja-aja". This is known } \\
\text { as apheresis. }\end{array}$ \\
\hline $\begin{array}{lll}\text { Komunikasi di } & \text { Warkop A } \\
\text { Pelanggan } 1 & : & \text { Enak } \\
\text { gak pisbakmu } & \text { itu? } & \text { Mari } \\
\text { kucoba dikit } & & \\
\end{array}$ & Pisbak & $\begin{array}{l}\text { - Berasal dari kata } \\
\text { Pisang - Pis } \\
\text { Bakar - Bak } \\
\text { The phrases of "Mari kucoba dikit", the }\end{array}$ \\
\hline
\end{tabular}

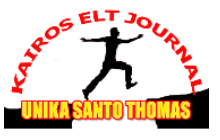




\begin{tabular}{|c|c|}
\hline 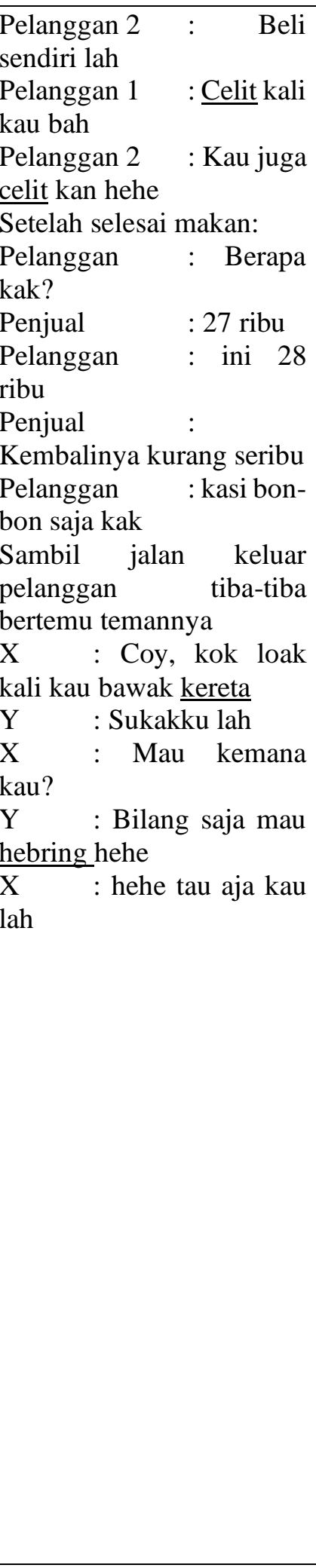 & $\begin{array}{l}\text { word "dikit" in the phrases above, there } \\
\text { is an omission at the beginning of the } \\
\text { word ":sedikit - dikit." This is known as } \\
\text { apheresis } \\
\text { The phrases of "Celit kali kau bah", the } \\
\text { accent is Tobanese, and the word "celit" } \\
\text { comes from the word "pelit" which } \\
\text { means as stingy. This is known as } \\
\text { hypercorrection. } \\
\text { The phrases "Dua puluh tujuh ribu" } \\
\text { should be completed with the word } \\
\text { rupiah behind it. } \\
\text { The phrases "Coy kok loak kali kau } \\
\text { bawak kereta", the word "coy" comes } \\
\text { from the word "konco" (from Javanese) } \\
\text { which means as friends. Then in a } \\
\text { familiar greeting it is shortened to Co- } \\
\text { Coy } \\
\text { The word "Loak" means it is outdated or } \\
\text { can also be interpreted very badly } \\
\text { The word "Bawak", there is a paragoge } \\
\text { with the addition of a sound at the end of } \\
\text { the word, "bawa-bawak" } \\
\text { The word "Sukakku lah", there is an } \\
\text { addition of a sound at the end of the word } \\
\text { "suka - sukak (paragoge) } \\
\text { The phrases "Bilang saja mau hebring", } \\
\text { the word "bilang" Is a non-standard word } \\
\text { it should be "katakan". The word } \\
\text { "hebring" is a term that means relax } \\
\text { The phrases "Tau aja" there is an } \\
\text { omission of the sound in the middle of } \\
\text { the word of "tahu". This is known as } \\
\text { syncope } \\
\text { This is knownere is as apheresis. }\end{array}$ \\
\hline
\end{tabular}

\section{Conclusion}

Following the findings and discussion, conclusions will be drawn in this chapter. The conclusions that will be described below are to answer the formulation of the problem as follows: 1 . Oral variety used by Linkungan II Titi Rantai Padang

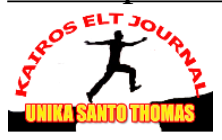




\section{KAIROS ELT JOURNAL, Vol. 5 No. 2 Agustus 2021}

Copyright $\bigcirc 2021$, ISSN: 2580-4278

Bulan a) The use of abbreviated terms is only understood by the people of the city of Medan, for example: mandi b) Spoken variety derived from foreign language abbreviations: otw, bro c) The use of abbreviations that are commonly known to everyone, for example: mantul, nasgor, pisbak, warkop 2. Oral variety in the choice of word forms often occurs language symptoms: a) Syncope language are the omission of sounds in the middle of words, for example: know-tau b) Apheresis language are the omission of sounds at the beginning of words, for example, just c) Haplological language are the omission of phonemes or sounds in the middle of words, for example: a little bit d) Paragog are changes in the sound at the end of the word, for example: Muka - mukak e) Construction, combining two words into one word, for example: how -> how f) Morphological, namely changing two sounds into one sound, for example: sampai - sampe g) Hypercorrect for example: Pelit celit 3. The use of oral variety by the community of Titi Chain Medan II Environment a) Influence local languages, for example: lappet, latteung, lalap b) The influence of foreign languages, for example: bro, otw c) The influence of the local language can be seen when reciting the spoken variety (Tobanese with a loud e sound)

\section{References}

Alek \& Achmad. 2011. Bahasa Indonesia untuk Perguruan Tinggi. Jakarta: Prenada Media Group

Chaer, Abdul. 1998. Tata Bahasa Praktis Bahasa Indonesia. Jakarta: Rineka Cipta

Barried, Baroroh. 1985. Pengantar Teori Filologi. Yogyakarta: Fakultas Sastra Universitas

Gadjah Mada

Gottschalk, Louis. 1986. Understanding History; A Primer of Historical Method (terjemahan Nugroho Notosusanto). Jakarta: UI Press.

Keraf, Gorys. 1980. Tata Bahasa Indonesia. Ende-Flores: Nusa Indah

Margono, S. 2010. Metode Penelitian Pendidikan. Jakarta: Rineka Cipta

Mulyono, Anton dkk.1989. Tata Bahasa Baku Bahasa Indonesia. Jakarta: Balai Pustaka

Nasution, S. 2003. Metode Penelitian Naturalistik-Kualitatif. Bandung: Tarsito.

Sugono, Dendy. 1994. Berbahasa Indonesia Dengan Benar. Jakarta: PT. Penebar Swadaya

Sugiyono. 2005. Memahami Penelitian Kualitatif. Bandung: ALFABETA. 